Tropical Journal of Pharmaceutical Research February 2017; 16 (2): 263-269

ISSN: $1596-5996$ (print); 1596-9827 (electronic)

(C) Pharmacotherapy Group, Faculty of Pharmacy, University of Benin, Benin City, 300001 Nigeria.

All rights reserved.

Available online at http://www.tjpr.org

Original Research Article

http://dx.doi.org/10.4314/tjpr.v16i2.2

\title{
Biosynthesis of lovastatin using agro-industrial wastes as carrier substrates
}

\author{
Sadia Javed ${ }^{1 *}$, Munazzah Meraj ${ }^{2}$, Saqib Mahmood ${ }^{3}$, Arruje Hameed ${ }^{1}$, Farah \\ $\mathrm{Naz}^{4}$, Sameera Hassan ${ }^{4}$ and Rao Irfan ${ }^{5}$ \\ ${ }^{1}$ Department of Applied Chemistry \& Biochemistry, Government College University, Faisalabad, ${ }^{2}$ Department of Biochemistry, \\ Peoples University of Medical and Health Sciences, Nawabshah, ${ }^{3}$ Department of Botany, Government College University, \\ Faisalabad, ${ }^{4}$ Centre of Excellence in Molecular Biology, University of Punjab, Lahore, ${ }^{5}$ Department of Pharmacy, Peoples \\ University of Medical and Health Sciences, Nawabshah, Pakistan
}

*For correspondence: Email: drsadiajaved@yahoo.com

\begin{abstract}
Purpose: To compare fungal strains including Aspergillus flavipes GCBL-72, Aspergillus flavus GCBL60, and Aspergillus niger GCBL-45 and determine whether solid- or liquid-state fermentation (SSF or $L S F)$ is more appropriate for lovastatin production using various inexpensive raw materials.

Methods: LSF and SSF techniques were used to produce the drug lovastatin. High-performance liquid chromatography was performed out to quantify lovastatin production. A kinetic growth model was applied to estimate product formation at the expense of substrate utilization.

Results: Aspergillus flavus GCBL-60 was a superior lovastatin-producing strain consuming wheat bran as the raw material in SSF. The optimum lovastatin production was $28.36 \pm 0.76 \mathrm{mg} / 100 \mathrm{~mL}$ at $35{ }^{\circ} \mathrm{C}$, pH 5.5, inoculum size $2 \mathrm{~mL}, 96 \mathrm{~h}$ incubation time, and $60 \%$ moisture content. Evaluation of the kinetic growth parameters for lovastatin production confirmed that product formation was improved after fermentation parameter optimization.

Conclusion: Our results indicate that Aspergillus flavus GCBL-60 was best lovastatin-producing strain and that SSF was superior to LSF for maximum production. Careful optimization can enhance product formation.
\end{abstract}

Keywords: Hypercholesterolemia, Kinetics, Optimization, Lovastatin, Solid-State Fermentation, Raw materials

Tropical Journal of Pharmaceutical Research is indexed by Science Citation Index (SciSearch), Scopus, International Pharmaceutical Abstract, Chemical Abstracts, Embase, Index Copernicus, EBSCO, African Index Medicus, JournalSeek, Journal Citation Reports/Science Edition, Directory of Open Access Journals (DOAJ), African Journal Online, Bioline International, Open-J-Gate and Pharmacy Abstracts

\section{INTRODUCTION}

Lovastatin has an important role in lowering blood cholesterol levels in both human and animals, thus diminishing the risk of hypercholesterolemia. It works by inhibiting the 3-hydroxy-3-methylglutaryl coenzyme A (HMG $\mathrm{CoA}$ ) reductase, thereby limiting the rate of cholesterol synthesis [1]. This compound is produced as a fungal secondary metabolite. Simvastatin can be derived from fermented lovastatin by enzymatic deacylation of lovastatin.
Various Aspergillus species such as Aspergillus niger, Aspergillus terreus, Aspergillus flavus, Aspergillus flavipes, Aspergillus parasiticus and some Monascus species including Monascus rubber, Monascus paxi, Monascus anka, and Monascus purpureus can produce this compound $[2,3]$.

Lovastatin was first isolated from Monascus rubber for commercial purposes, but Aspergillus terreus remains the organism of choice for lovastatin biosynthesis. The lovastatin produced 
in fermentation broth medium is the open hydroxy form, which is the biologically active form. The synthetic form of lovastatin is always the lactone form, which is converted to the open hydroxy acid form in vivo (Fig. 1) when administered to patients [4]. The solid-state fermentation (SSF) technique is considered to be the best approach for lovastatin production using fungal strains because it offers numerous advantages over liquid-state fermentation (LSF) such as low energy requirements, less waste water, and a large surface area for fungal growth [5-7]. In addition to treating hypercholesterolemia, lovastatin has other clinical applications for coronary heart disease, Alzheimer disease, renal diseases, cancer, bone fracture disease, and multiple sclerosis [8-10].

The present project was designed to identify the best lovastatin-producing fungal strain and optimize fermentation parameters using agro industrial wastes as carrier substrates. This information is valuable for enhancing the bulk production of the cholesterol-lowering drug lovastatin using indigenous sources, which facilitates environmental friendly management of renewable resources.

A<smiles>CCC(C)C(=O)OC1CC(C)C=C2C=C[C@H](C)C(CCC3C[C@@H](O)CC(=O)O3)C21</smiles>

B<smiles>CCC(C)C(=O)OC1CC(C)C=C2C=C[C@H](C)C(CCC(O)C[C@H](O)CC=O)C21</smiles>

Figure 1: Structural formulae of the $(A)$ lactone and (B) open hydroxy acid forms of lovastatin

\section{EXPERIMENTAL}

The pure cultures of fungal strains were isolated by our research group and grown on potato dextrose agar (PDA) slants. They were stored in a refrigerator at $4^{\circ} \mathrm{C}$ to avoid contamination.

\section{Inoculum preparation}

Vogel's medium $\left(\mathrm{KH}_{2} \mathrm{PO}_{4}, 0.5\right.$; peptone, 0.1 ; yeast extract, $0.2 ; \mathrm{NH}_{4} \mathrm{NO}_{3}, 0.2 ;\left(\mathrm{NH}_{4}\right)_{2} \mathrm{SO}_{4}, 0.4$; $\mathrm{MgSO}_{4}, 0.02$; glucose, $50 \%$; trisodium citrate, $0.5 \mathrm{~g} / 100 \mathrm{~mL}$ ) was prepared in $500-\mathrm{mL}$ flasks. The medium $\mathrm{pH}$ was maintained at 5.5 using $0.1 \mathrm{M} \mathrm{NaOH} / \mathrm{HCl}$ solutions. It was sterilized in an autoclave at $121{ }^{\circ} \mathrm{C}$ for $15 \mathrm{~min}$. Fungi spores were picked by loop and added into the flask. These flasks were positioned in an orbital shaker at $120 \mathrm{rpm}$ for $48 \mathrm{~h}\left(30^{\circ} \mathrm{C}\right)$.

\section{Spore quantification}

Spores were counted using a hemocytometer under low-power microscope using the method of Kolmer et al [11].

\section{Fermentation medium cultivation}

A comparison of two fermentation techniques was made using $250-\mathrm{mL}$ conical flasks kept in a temperature-controlled incubator. For SSF, $5 \mathrm{~g}$ wheat bran was placed in triplicate flasks, and inoculum medium was added to keep the substrate at $60 \%$ moisture. After maintaining the $\mathrm{pH}$ at 5.5, the flasks were sterilized in an autoclave for $15 \mathrm{~min}$ at $121{ }^{\circ} \mathrm{C}$. Next, $5 \mathrm{~mL}$ spores of individual fungal strains were inoculated in separate flasks and placed in an incubator for $72 \mathrm{~h}$. For LSF, $100 \mathrm{~mL}$ Vogel medium was placed in $250-\mathrm{mL}$ conical flasks. The samples weresterilized at $121^{\circ} \mathrm{C}$ for $15 \mathrm{~min}$ in an autoclave after verifying the $\mathrm{pH}$. After cooling to room temperature, they were inoculated with $5 \mathrm{~mL}$ of fungal spores individually and kept at $30^{\circ} \mathrm{C}$ for $72 \mathrm{~h}$ on a shaker.

\section{Lovastatin extraction}

For SSF, distilled water was added to bring the volume up to $100 \mathrm{~mL}$, and the flasks were placed on a shaker for $1 \mathrm{~h}$. These flasks were then acidified with $10 \% 1 \mathrm{~N} \mathrm{HCl}$ to $\mathrm{pH} 3.0$ after $72 \mathrm{~h}$ for both SSF and LSF. An equal volume of ethyl acetate was added to the acidified broth, which was kept on a shaker for $2 \mathrm{~h}$ at $70^{\circ} \mathrm{C}$. This broth was filtered to separate out the biomass and filtrate, followed by centrifugation at $4,000 \mathrm{~g}$ for 8 min before the upper phase was collected. Next, $10 \mathrm{~mL} 1 \%$ trifluoroacetic acid was added to $1 \mathrm{~mL}$ 
of the organic phase for the lactonization process, and the extract was vaporized at $80^{\circ} \mathrm{C}$.

\section{Analytical procedures}

Lovastatin samples were analyzed using highperformance liquid chromatography (HPLC). The concentrated lovastatin was diluted at a 1:1 ratio with acetonitrile and passed through a filtration assembly $(0.45 \mu \mathrm{m})$ The samples $(20 \mu \mathrm{L})$ were injected into the HPLC apparatus (Shimadzu LC10AT) by syringe and analyzed with a UV detector at $238 \mathrm{~nm}$ and Shim pack CLS-ODS (C18) column at a flow rate of $1 \mathrm{~mL} / \mathrm{min}$. The mobile phase consisted of $0.1 \%$ phosphoric acid and acetonitrile with a volume ratio of $40: 60$ [12].

\section{Kinetic growth parameter determination}

All kinetic parameters for lovastatin yield and biomass were calculated by the method as described by Okpokwasili and Nweke [13]. The kinetic parameters were studied before and after optimization of culture conditions in the fermentation process.

\section{Statistical analysis}

Comparisons of means were done by Duncan's multiple range (DMR) tests, and the statistical significance of differences among means was estimated by analysis of variance (ANOVA) under a complete randomized design [14].

\section{RESULTS}

This study was performed to screen three Aspergilli strains (Aspergillus flavipes GCBL-72, Aspergillus flavus GCBL-60, and Aspergillus niger $G C B L-45)$ and compare two fermentation techniques for natural lovastatin production using wheat bran, wheat straw, corn stover, and banana stalk as carrier substrates. It was found that the Aspergillus flavus GCBL-60 strain had

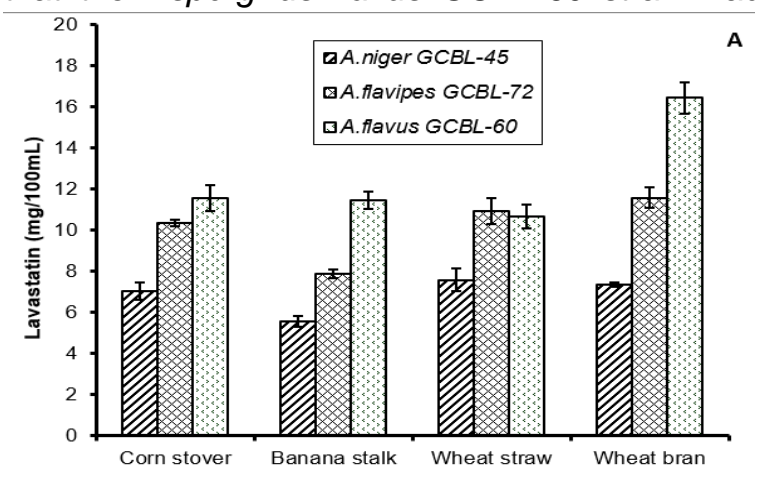

the best capacity to produce lovastatin (23.57士 $1.31 \mathrm{mg} / 100 \mathrm{~mL}$ ) using wheat bran and the SSF technique (Figure 2) as compared with the LSF technique $(16.42 \pm 2.61 \mathrm{mg} / 100 \mathrm{~mL})$.

\section{Fermentation parameter optimization}

An optimum $\mathrm{pH}$ is necessary for all biological processes because living things are sensitive to $\mathrm{pH}$ change. The greatest amount of lovastatin was produced $(23.33 \pm 1.57 \mathrm{mg} / 100 \mathrm{~mL})$ with a dry cell mass $(5.83 \pm 0.051 \mathrm{~g})$ at $\mathrm{pH} 5.5$ by Aspergillus flavus GCBL-60 (Figure 3A) using SSF. Initially, lovastatin production was enhanced by increasing the $\mathrm{pH}(3.0-5.5)$, and it was gradually decreased by further increasing the $\mathrm{pH}$.

Temperature is one of the most useful fermentation factors to optimize because it has a direct influence on lovastatin production. The maximum yield of lovastatin obtained was 25.30 $\pm 1.75 \mathrm{mg} / 100 \mathrm{~mL}$ with a dry cell mass of $6.36 \pm$ $0.93 \mathrm{~g}$ by Aspergillus flavus GCBL-60 at $35^{\circ} \mathrm{C}$ (Figure 3B).

To attain maximize lovastatin yield, media were prepared in different conical flasks with various inoculum sizes $(1.0-5.0 \mathrm{~mL})$. The maximum lovastatin yield $(26.68 \pm 1.34 \mathrm{mg} / 100 \mathrm{~mL})$ and dry cell mass $(6.34 \pm 1.21 \mathrm{~g})$ were found at 3.0 (Figure 3C). Moisture content optimization is necessary for maximum production of secondary metabolites in SSF. A lower moisture level is very important to avoid fermentation medium contamination and suboptimal product formation due to reduced mass transfer processes, such as diffusion of gas and solutes to the cell. It was observed that the maximum lovastatin yield (27.88 $\mathrm{mg} / 100 \mathrm{~mL}$ ) was obtained at $60 \%$ moisture content using wheat bran by Aspergillus flavus GCBL-60 (Figure 3D).

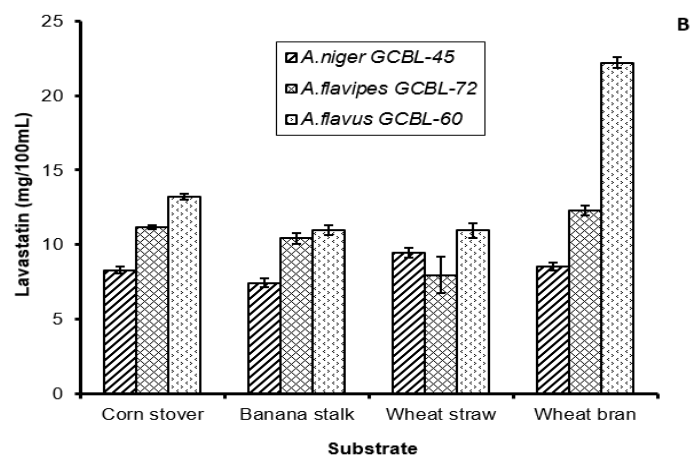

Figure 2: Screening of three fungal strains (Aspergillus niger GCBL-45, Aspergillus flavipes GCBL72, and Aspergillus flavus GCBL-60) for lovastatin production in (A) LSF and (B) SSF. Values (mean \pm $\mathrm{SD}, \mathrm{n}=3, p \leq 0.05)$ 

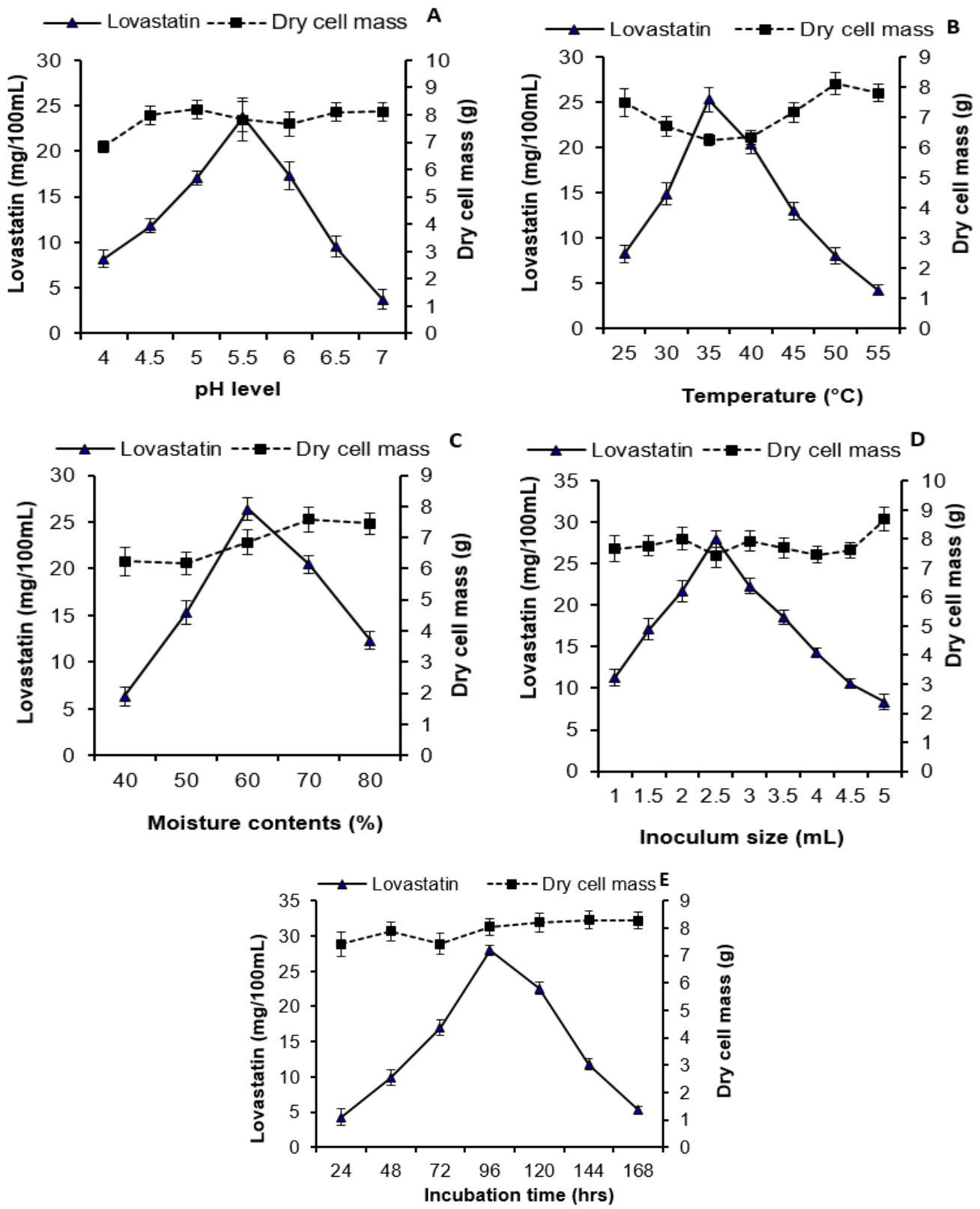

Figure 3: Effects of $(A) \mathrm{pH},(B)$ temperature, $(C)$ inoculum size, (D) moisture content and incubation time on lovastatin production by Aspergillus flavus GCBL-60 using wheat bran in SSF. Values (mean \pm SD, $n=3, p \leq 0.05$ )

Time is one of the most important factors for optimizing any fermentation medium. It was found that the optimum incubation time was $96 \mathrm{~h}$ with maximum lovastatin production (28.41 \pm $0.33 \mathrm{mg} / 100 \mathrm{~mL}$ ) for Aspergillus flavus GCBL-60 (Figure $3 \mathrm{E})$. A longer incubation time did not enhance lovastatin production. This might be due to fungal strain age, nutrient depletion, and low nitrogen availability in the medium.

\section{Kinetic parameters}

Kinetic parameters of substrate consumption and product formation were estimated before and after optimization of lovastatin production by Aspergillus flavus GCBL-60 (Table 1). After optimization, the highest lovastatin quantity $(28.41 \pm 0.33 \mathrm{mg} / 100 \mathrm{~mL})$ was noted for Aspergillus flavus GCBL-60. Growth parameters were also compared before and after optimization (Table 1). Before optimization, Aspergillus flavus GCBL-60 exhibited levels of substrate consumption parameters $\mathrm{Yx} / \mathrm{s}$ and $\mathrm{Yp} / \mathrm{X}$ and product formation parameter $\mathrm{Yp} / \mathrm{s}$ (1.43, 3.18 and $0.44 \mathrm{mg} / \mathrm{g}$, respectively). On optimization, it was observed that these growth parameters were further enhanced to $2.74,5.60$ and $0.489 \mathrm{mg} / \mathrm{g}$, respectively (Table 1). It was also observed that the $Q_{s}, q_{s}$, and $Y x / s$ parameters significantly increased after optimization, indicating that Aspergillus flavus 
Table 1: Kinetic parameters for lovastatin production by Aspergillus terreus GCBL-60 in SSF

\begin{tabular}{|c|c|c|c|}
\hline $\begin{array}{l}\text { Kinetic } \\
\text { parameter }\end{array}$ & $\begin{array}{l}\text { Aspergillus flavus GCBL- } \\
60\end{array}$ & Pre-optimization & Post-optimization \\
\hline Substrate & ${ }^{A} \mu\left(h^{-1}\right)$ & 0.084 & 0.190 \\
\hline \multirow{4}{*}{ consumption } & ${ }^{B} Y X / s$ & 1.43 & 2.74 \\
\hline & ${ }^{\mathrm{G}} \mathrm{Yp} / \mathrm{x}$ & 3.18 & 5.60 \\
\hline & ${ }_{\mathrm{qs}}^{\mathrm{qs}}(\mathrm{g} / \mathrm{g} / \mathrm{h})$ & 0.023 & 0.021 \\
\hline & ${ }^{\mathrm{E}} \mathrm{Qs}(\mathrm{g} / \mathrm{L} / \mathrm{h})$ & 0.16 & 0.11 \\
\hline \multirow[t]{4}{*}{ Product formation } & ${ }^{r} \mathrm{Qx}(\mathrm{g} / \mathrm{L} / \mathrm{h})$ & 0.072 & 0.056 \\
\hline & ${ }^{G} Y p / s$ & 0.44 & 0.489 \\
\hline & ${ }^{\mathrm{H}} \mathrm{qp}($ Product/h/g) & 0.033 & 0.058 \\
\hline & 'Qp (Product/L/h) & 0.23 & 0.314 \\
\hline
\end{tabular}

GCBL-60 grew faster under the new conditions. The maximum product formed $\left(Q_{P}\right)$ was 0.23 $\mathrm{g} / \mathrm{L} / \mathrm{h}$ before optimization, and this improved to $0.314 \mathrm{~g} / \mathrm{L} / \mathrm{h}$ after optimization.

\section{DISCUSSION}

Fermentation is a technique that produces secondary metabolites using inexpensive raw materials under SSF. It offers major advantages including cost-effective raw material, simple downstream processing, and less water use [15]. In SSF, fungus directly adsorbs on the substrate and uses it as an energy source to secrete a higher amount of the desired product. Substrate particle size is very important to provide higher porosity for better heat and mass transfer for maximum lovastatin production. Highest lovastatin production ( $85.88 \mathrm{mg} / \mathrm{L}$ ) by Aspergillus flavus UICC 360 was reported by Mangunwardoyo et al [16], and a maximum lovastatin concentration $(113 \mu \mathrm{g} / \mathrm{mL})$ by $P$. ostreatus was observed by Lakshmanan and Radha [17].

Biological fluids are very sensitive to changes in physiological $\mathrm{pH}$. However, maximum lovastatin production was observed at $\mathrm{pH} 7.0$ by Latha et al [22]. We found that further increase in $\mathrm{pH}$ decreases product formation, while low $\mathrm{pH}$ prevents contamination and also denatures or inactivates the fungal strain. The $\mathrm{pH}$ range for most of the fungi is reported as 3.5-7.0. The $\mathrm{pH}$ affects the transport of different ions and substances across the cell membrane, which supports product formation and cell growth [1].

Fermentation medium temperature is one of the most important factors that directly influences microorganism growth. Temperature affects the production of secondary metabolites, and this effect is variable according to media composition. It was previously reported that the maximum lovastatin production occurs at $28^{\circ} \mathrm{C}$, and further increases in temperature decrease the yield [19]. Optimum lovastatin production was observed at $30{ }^{\circ} \mathrm{C}$. This temperature might be best for the sporulation, proliferation, and growth of mycelial masses. However, Attalla et al [20] obtained maximum lovastatin production at $28-30^{\circ} \mathrm{C}$.

Appropriate inoculum size is necessary in SSF processes because inappropriate sizes may lead to inaccurate data. Inoculum with too few spores may lead to insufficient biomass, while too many spores results in biomass overproduction and subsequent depletion of nutrients in the medium. These findings are in agreement with those of Latha et al [22], who reported the highest amount of lovastatin produced with a $2 \%$ culture of Aspergillus fischeri. Some other studies reported varying inoculum size; Hajjaj et al [21] and Samiee et al [23] found that 3 and $10 \%$ inoculum sizes, respectively, were best for maximum lovastatin production by Aspergillus terreus.

Moisture content is one of the most critical factors affecting SSF. An optimum moisture level minimizes the risk of fermentation medium contamination. Low moisture may support the availability of sufficient oxygen, but it also reduces metabolic activity, which may decrease lovastatin production. Conversely, higher moisture level decreases oxygen availability due to insufficient air present in the void volume and poor lovastatin production. It was evident from our study that the $2 \%$ inoculum size yielded the most lovastatin, and further increasing moisture content lowered production. Latha et al [22] reported the highest lovastatin yield at $60 \%$ moisture content.

Incubation time is another important factor to optimize for maximum lovastatin production with SSF. It is generally considered that a short fermentation period can effectively contribute to increasing profitability on an industrial scale. Lovastatin is a secondary metabolite produced 
during the stationary phase of growth [24]. Latha et al [22] reported a maximum yield of lovastatin at $7.43 \mathrm{mg} / \mathrm{g}$ of dry substrate with $168 \mathrm{~h}$ of fermentation time. Maximum lovastatin production after $96 \mathrm{~h}$ may be due to the fact that it was produced as a result of the secondary microorganism growth. The subsequent decrease in lovastatin production was due to feedback inhibition by the existing lovastatin. Mukhtar et al [24] found maximum lovastatin production $(1,699.87 \pm 0.08 \mu \mathrm{g} / \mathrm{mL})$ by Aspergillus terreus after $120 \mathrm{~h}$ incubation.

Overall, kinetic parameters exhibited maximum product formation on substrate utilization during the fermentation process. Haq et al [25] reported that the cell growth rate of $A$. niger GCB-16 was $0.193 / h$ by GCB-16 for citric acid production. Moreover, Ali et al [26] found that the cell growth rate of Aspergillus niger was $0.122 / \mathrm{h}$. However, our selected strain Aspergillus flavus GCBL-60 showed the maximum cell growth rate following fermentation profile optimization.

\section{CONCLUSION}

The findings of current study indicate that the combination of Aspergillus flavus with wheat bran and solid state fermentation technique is best for maximum lovastatin production.

\section{DECLARATIONS}

\section{Acknowledgement}

This project was funded by Higher Education Commission (HEC), Islamabad, Pakistan under Interim Placement for PhDs (IPFP).

\section{Conflict of Interest}

No conflict of interest associated with this work.

\section{Contribution of Authors}

The authors declare that this work was done by the authors named in this article and all liabilities pertaining to claims relating to the content of this article will be borne by them.

\section{Open Access}

This is an Open Access article that uses a funding model which does not charge readers or their institutions for access and distributed under the terms of the Creative Commons Attribution License (http://creativecommons.org/licenses/by 14.0) and the Budapest Open Access Initiative (http://www.budapestopenaccessinitiative.org/rea d), which permit unrestricted use, distribution, and reproduction in any medium, provided the original work is properly credited.

\section{REFERENCES}

1. Valera HR, Gomes J, Lakshmi S, Gururaja R, Suryanarayan $S$, Kumar D. Lovastatin production by solid state fermentation using Aspergillus flavipes. Enz Microb Tech, 2005; 37: 521-526.

2. Harsha SS, Sridevi V, Chandana LMVV, Kiran $T$. Production of Mevastatin by Solid State Fermentation Using Sesame Oil Cake. Res J Pharm Biol Chem Sci, 2013; 4: 429-436.

3. Hanukoglu I. Steroidogenic enzymes structure, function, and role in regulation of steroid hormone biosynthesis. $J$ Ster Biochem Mol Biol, 1992; 43: 779-804.

4. Daborah RA, Lein J, Conder MJ, Tewalt GL. Enzymatic deacylation of simvastatin. U.K. Patent, 1992; 2: 255974.

5. Wei $P, X u Z$, Cen P. Lovastatin production by Aspergillus terreus in solid state fermentation. J Zhej Uni Sci $A$, 2007; 8: 1521-1526.

6. Xu BJ, Wang QJ, Jia XQ, Sung CK. Enhanced lovastatin production by solid state fermentation of Monascus rubber. Biotechnol Bioproc Eng, 2005; 10: 78-84.

7. Ragunath R. Radhakrishna A, Manikandan N, Nathiya K, Palaniswamy $M$. Optimised production of lovastatin through solid state fermentation by endophytic fungi. Int J Pharm Bio Sci, 2012; 3: 562-570.

8. Klawitter J, Shokati T, Moll V, Christians U, Klawitter J. Effects of lovastatin on breast cancer cells a proteometabonomic study. Bre Can Res, 2010; 12: 16-32.

9. Stojadinovic O, Lebrun EA, Pastar I, Kirsner RS, Davis SC. Statins as Potential Therapeutic Agents for Healing Disorders. Exp Rev Derm, 2010; 5: 689-698.

10. Seraman S, Rajendran A, Thangavelu V. Statistical optimization of anticholesterolemic drug lovastatin production by the red mold Monascus purpureus. F Bioprod Pro, 2010; 8: 266-276.

11. Kolmer JA, Spaulding EH, Robinson HW. Approved laboratory techniques 5th ed. Appleton. New York. 1959.

12. Morovjan G, Szakacs G, Fekete F. Monitoring of selected metabolites and biotransformation products from fermentation broths by high-performance liquid chromatography. J Chrom A, 1997; 763: 165-172.

13. Okpokwasili GC, Nweke CO. Microbial growth substrate utilization kinetics. Afr J Biotech, 2005; 5: 305-317.

14. Steel FG, Torrie H, Dickey DA. Principles and procedures of a biometrical approach. 3rd edition. W. C. McGraw hill, New York. 1979.

15. Szakacs G, Morovjan G, Tengerdy RP. Production of lovastatin by a wild strain of Aspergillus terreus. Biotech. Lett, 1998; 20: 411-415.

16. Mangunwardoyo W, Rafliyanti $Y$, Kusmana $D$. Bioprospect of lovastatin in Aspergillus spp. from 
University of Indonesia Culture Collection (UICC).W App Sci J, 2012; 16: 183-188.

17. Lakshmanan, D, Radha KV. An Effective Quantitative Estimation of Lovastatin from Pleurotus Ostreatus using UV and HPLC. Int J Pharm Pharm Sci, 2012; 4: 0975 1491.

18. Prabhakar M, Lingappa $K$, Babu V, Aamena $S$, Vishalakshi N, Mahesh D Characterization of physical factors for optimum lovastatin production by Aspergillus Terreus under solid state fermentation. J Rec Adv App Sci, 2012; 27: 01-05.

19. Aparna DG, Reddy DSR. Production of lovastatin by Aspergillus parasiticus NCIM 696 using rice bran under solid state fermentation. J Chem Biol Phy Sci, 2010; 2 : 284-291.

20. Atalla MM, Hamed ER, El-Shami AR. Optimization of a culture medium for increased mevinolin production by Aspergillus terreus strain. Malay J Microb, 2008; 4: 6-10.

21. Hajjaj $H$, Niederberger $P$, Duboc $P$. Lovastatin Biosynthesis by Aspergillus terreus in a Chemically
Defined Medium. Appl Environ Microb, 2001; 67: 25962602.

22. Latha $P M$, Chanakya $P$, Srikanth $M$. Lovastatin production by Aspergillus fischeri under solidstate fermentation from coconut oil cake. Nep $J$ Biotech, 2012; 2: 26-36.

23. Samiee SM, Moazami N, Haghighi S, Mohseni FA, Mirdamadi S. Screening of Lovastatin Production by Filamentous Fungi. Ira Biomed J, 2003; 7: 1-5.

24. Mukhtar H. ljaz SS, Haq I. Upstream and Downstream Processing of Lovastatin by Aspergillus terreus. Cell Biochem Biophys, 2014; 70: 309-320

25. Haq IU, Ali S, Qadeer MA, Javed I. Control of Aspergillus niger morphology to enhance citric acid production under liquid culture. Pak J Bot, 2003; 35: 533-539.

26. Ali S, Haq I, lqbal J. Effect of low $\mathrm{pH}$ on continuous citric acid fermentation by Aspergillus niger. Pak J Bot, 2005; 37: 981-987. 